\title{
The interpersonal skills of recent U.S. entrants to the field of healthcare management
}

\author{
Diane M. Howard ${ }^{1}$, Douglas M. Silverstein ${ }^{2}$ \\ 1. Department of Health Systems Management, Rush University, Chicago, USA. 2. North Shore University Health System \\ - Evanston Hospital, Chicago, USA.
}

Correspondence: Diane M. Howard. Address: Department of Health Systems Management, Rush University, 1700 W. Van Buren Street, TOB126B, Chicago, IL 60612 USA. E-mail: Diane_M_Howard@rush.edu

Received: August 8, 2013

Accepted: December 18, 2013

Online Published: December 25, 2013

DOI : $10.5430 /$ jha.v3n3p33

URL: http://dx.doi.org/10.5430/jha.v3n3p33

\begin{abstract}
A national survey was conducted to determine the current state of senior executive perceptions of recent entrant managers within corporate headquarters, hospital systems, and freestanding hospitals. The survey was constructed based on leadership interpersonal competencies and competency-based career development programs. A total of 676 respondents returned a survey, representing $31 \%$ of the mailing sample.

The goal of the research was to determine the perceptions that senior executives have about the interpersonal skills of recent entrants to the field of health care management and identify best practices for organizational training of such entrants. Findings reveal that senior executives view the recent entrant manager favorably regardless of age, gender, education, and non-clinical/clinical background. Senior executives also observed the need to require additional training of recent entrant managers in areas of management skills on understanding organizational politics, using a variety of techniques to influence others, handling difficult people or situations using diplomacy, confronting others about their mistakes, and exercising authority.
\end{abstract}

\section{Key words}

Early careerists, Entry-level managers, Generational differences, Millennials, Work ethic, Healthcare leadership training, Interpersonal skills

\section{I ntroduction}

The generation divide in the workplace has consumed attention in the print and broadcast media. Workplace professionals comment on the generational differences in how senior executives and early careerists approach the nature of their jobs. It is important to know specifically the perceptions of the senior chief executives about the interpersonal skills of recent entrants to the field of healthcare management (REM).

The American College of Healthcare Executives (ACHE) issued a Request for Proposal to pursue research on the topic of interpersonal skills. A national survey was conducted to determine the current state of senior executive perceptions of recent entrants within corporate headquarters, hospital systems, and freestanding hospitals. The survey was constructed based on leadership interpersonal competencies and competency-based career development programs. A total of 676 respondents returned a survey, representing $31 \%$ of the mailing sample. 
The goal of the research was to determine the perceptions that senior executives have about the interpersonal skills of REMs and to identify best practices for organizational training of REMs to the field of health care management. The research questions are: to what extent are interpersonal competencies viewed as important skills to possess in management? How effective are REMs in demonstrating these competencies on the job? And what are health companies doing to enhance the skills of REMs?

\subsection{Generational differences}

Differences across generations can present challenges to optimal working relationships and organizational coherency ${ }^{[1]}$. Leading healthcare organizations have begun to recognize these challenges and addressed them through additional education. For example, the Mayo Clinic's website provides strategies to improve the working relationships between the generational cohorts with the following formula: (1) Beware of the differences; (2) Appreciate the strengths of each group; and (3) Manage the differences effectively ${ }^{[2]}$. Strategies for better communication between groups are enhanced when the interaction builds upon each cohort's unique characteristics.

Howe and Strauss divided the American workforce into four distinct "generations" in 20-year cohorts: Traditionalists (born between 1925 and 1945), Baby Boomers (1946 and 1964), Gen Xers (1965 and 1979), and Gen Yers or Millennials (1980 and 2001) ${ }^{[3]}$. According to Alsop, each twenty-year cohort has characteristics distinct to the group which stem from events and cultural factors taking place during the key phases of their development, differences that are also reflected in how each group approaches their work ${ }^{[4]}$. The Howe and Strauss and Alsop research form the taxonomy of this interpersonal analysis.

In addition to social and economic changes influencing development, healthcare leaders may be influenced by the nature and climate within which their profession operated at key points during their career.

\subsection{Intergenerational communication and conflict}

According to Cahill and Sedrak ${ }^{[5]}$, tension among the generations is particularly acute between the boomers and millennials (generation Y). Recruiters find millennials to be overly demanding when it comes to needing guidance, ongoing feedback, career advancement, and work-life balance, a term that was unheard of for boomers who gave all to the organization to secure advancement. Boomers will refer to millennials as "slackers" because they are perceived to be much less willing to make personal sacrifices for the good of their employers ${ }^{[4,6]}$. The generational shift to millennials is exacerbated by the ethnically and racially diverse nature of the millennials. In a study of US college freshman trends, University of California at Los Angeles found that there were jumps in education enrollment for Asians from $0.6 \%$ in 1971 to $8.6 \%$ in 2006, and Latin American students from $0.6 \%$ to $7.3 \%{ }^{[7]}$. In addition, the gender shift has become more pronounced with college and graduate school enrollment at $55 \%$ for females ${ }^{[7]}$.

\subsection{Graduate education and early career experiences}

In recognition of some of the challenges new healthcare managers faced in acculturating to the workplace, the Commission on the Accreditation of Healthcare Management Education added Interpersonal Effectiveness and Professionalism to its list of content areas that accredited programs are required to teach ${ }^{[8]}$. As a result, professionalism courses are now taught in many graduate programs of health management ${ }^{[9]}$. These programs assist students in developing resumes and cover letters, prepare them for the interview experience through audio and video recordings, identify mentors and advise them on salary negotiation, and even provide dining etiquette instruction. Although these are important skills, effectiveness in communicating across generations and interpersonal skills do not get the attention they deserve ${ }^{[10]}$.

\section{Methods}

The ACHE survey to assess REM interpersonal skills was fielded using web-based solicitations for participation. The sample consisted of 2200 senior executives from the American College of Healthcare Executives membership. The 
electronic surveys were distributed along with a cover letter explaining the purpose of the survey. The survey contained a screener question that inquired if the senior executive could identify a REM with whom he or she worked on a regular basis. The REM was defined as an individual 30 years of age or less who had been a healthcare management professional for five years or less. In three weeks following the electronic solicitation, 1,301 faxes were directed to nonresponders from the initial web-based solicitation. A total of 676 respondents returned the survey from the two solicitations, which represented $31 \%$ of the 2,200 affiliates originally sampled. Of the 676 surveys, 9\% (61) did not complete the full survey. This left 615 (91\%) completed surveys, which were used.

\subsection{Demographics of senior executive respondents}

Sixty-nine percent of the respondents are male and 31\% are female. The race/ethnicity of the respondents is Caucasians/ Whites - 94\%; African Americans/Blacks - 3\%; Hispanics - 2\%; and Asians/Pacific Islanders - 1\%. The degree programs completed were in the following areas: Health Management (50\%); Business Administration - 28\%; Clinical/Allied Health $-15 \%$; and Others $-7 \%$. The self-reported positions of the respondent senior executive population are Chief Executive Officer - 42\%; Chief Operating Officer - 14\%; Chief Financial Officer - 3\%; Chief Information Officer - 1\%; Chief Medical Officer - 1\%; Chief Nursing Officer - 7\%; Senior Vice President - 6\%; and Vice President - 25\%. The work settings of the senior executive respondents were Freestanding Hospital - 55\%; System Hospital - 32\%; and Corporate Headquarters $-13 \%$. The mean age of the respondents was 53 years. Fifty-two percent (319) of the respondents reported that they could identify a REM with whom they worked on a regular basis. The capacity in which the senior executive interacted with the REM was primarily as an immediate supervisor (39\%); formal mentor (14\%); informal mentor (22\%); work group participant (17\%); and has an office near the recent entrant manager (8\%).

\subsection{Demographics of REMs}

The mean age of the REM is 29 years of age. Fifty-four percent of the REMs are female and $46 \%$ are male. Of the 297 REMs where the senior executive knew their marital status, $66 \%$ of the REMs are married and $29 \%$ are single. Of the 297 REMs, 52\% have no children and 48\% have children. The race/ethnicity distribution of the REMs is: Caucasian/White 79\%; African-American/Black - 9\%; Hispanic - 5\%; and Asian - 5\%. The academic major of the REMs is Health Management (50\%); Business (23\%); Clinical and Allied Health (includes medicine, nursing, and science-related degree programs) (10\%); and Others (include community health, legal, and public administration) (1\%). Sixteen percent did not have a graduate degree (see Figure 1). While there were 615 completed surveys, only 297 senior executives knew the marital status of their REM.

Figure 1. Educational status of REMs

Note. The numbers appearing in the narrative vary by respondent.

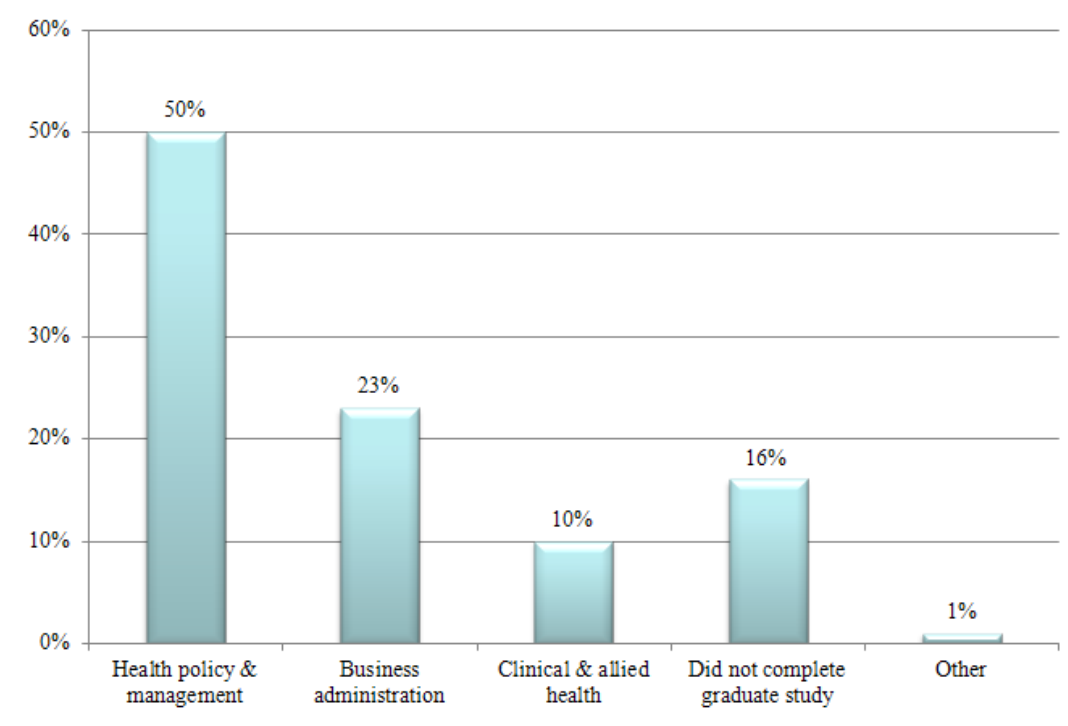




\section{Assessment of the REM}

\subsection{I ntrapersonal and interpersonal attributes}

To assess the intrapersonal and interpersonal characteristics of the REM, evaluators were presented with 26 items derived from suggestions from focus group respondents, a preliminary survey and the pertinent literature. The focus group respondents were healthcare executives in the American College of Healthcare Executives and the National Association of Health Services Executives who assisted in identifying intrapersonal and interpersonal attributes that were necessary for REMs to be successful. To assist in interpreting the findings, the 26 questions were divided into four categories: (1) intrinsic qualities, (2) self development, (3) outlook, and (4) management skills (see Tables 1-4).

Respondents were asked to rate their REM on a five point scale where "1" indicates poor performance or possession of an attribute, " 2 " represents fair or somewhat below average, " 3 " indicates average performance or possession of the attribute, " 4 " indicates above average competence, and “ 5 ” indicates superior performance or possession of a positive attribute.

\subsubsection{I ntrinsic qualities}

Four attributes comprised this category: (1) the REM's personal values being consistent with the management team values, (2) the REM being honest about mistakes the REM made, (3) ease for evaluator to trust the REM, and (4) ease for others to trust the REM.

The researchers evaluated the intrinsic qualities of the four statements by summing the proportion of REMs that were assessed "below average" (i.e., scores of 1 or 2) and contrasted this with the proportion that rated their REM above average," (i.e., scores of 4 or 5). Overall, (with) regard to these four attributes, evaluators scored their REM positively. Seventy-five percent or more of the evaluators gave their REMs above average ratings.

Only between $7 \%$ and $9 \%$ of REMs were evaluated negatively on their intrinsic qualities. The average negative score on this dimension was 8. The largest proportion of negative scores (9\%) was that "others find it easy to trust this manager". Eight percent stated that their REM's personal values were not always consistent with the management team. As many as $8 \%$ stated that the manager was below average in being honest about his mistakes. Only seven percent said they found it difficult to trust their REM.

Table 1. Senior executive evaluations of their REM on intrinsic qualities dimension - row percentages

\begin{tabular}{|c|c|c|c|c|c|c|}
\hline & \multicolumn{2}{|c|}{ Negative } & \multirow{2}{*}{$\begin{array}{l}\text { Medium } \\
3\end{array}$} & \multicolumn{2}{|c|}{ Positive } & \\
\hline & 1 & 2 & & 4 & 5 & \\
\hline $\begin{array}{l}\text { This manager's personal } \\
\text { values are not consistent with } \\
\text { the management team }\end{array}$ & $\begin{array}{l}1 \\
(1 \%)\end{array}$ & $\begin{array}{l}24 \\
(8 \%)\end{array}$ & $\begin{array}{l}43 \\
(13 \%)\end{array}$ & $\begin{array}{l}133 \\
(40 \%)\end{array}$ & $\begin{array}{l}126 \\
(38 \%)\end{array}$ & $\begin{array}{l}\text { This manager's personal } \\
\text { values are always consistent } \\
\text { with the management team }\end{array}$ \\
\hline $\begin{array}{l}\text { This manager is not always } \\
\text { honest about his mistakes }\end{array}$ & $\begin{array}{l}2 \\
(1 \%)\end{array}$ & $\begin{array}{l}21 \\
(6 \%)\end{array}$ & $\begin{array}{l}27 \\
(8 \%)\end{array}$ & $\begin{array}{l}84 \\
(26 \%)\end{array}$ & $\begin{array}{l}191 \\
(59 \%)\end{array}$ & $\begin{array}{l}\text { This manager is honest } \\
\text { about his mistakes }\end{array}$ \\
\hline $\begin{array}{l}\text { I find it difficult to trust this } \\
\text { manager }\end{array}$ & $\begin{array}{l}4 \\
(1 \%)\end{array}$ & $\begin{array}{l}18 \\
(6 \%)\end{array}$ & $\begin{array}{l}34 \\
(10 \%)\end{array}$ & $\begin{array}{l}91 \\
(28 \%)\end{array}$ & $\begin{array}{l}179 \\
(55 \%)\end{array}$ & $\begin{array}{l}\text { I find it easy to trust this } \\
\text { manager }\end{array}$ \\
\hline $\begin{array}{l}\text { Others do not find it easy to } \\
\text { trust this manager }\end{array}$ & $\begin{array}{l}5 \\
(2 \%)\end{array}$ & $\begin{array}{l}23 \\
(7 \%)\end{array}$ & $\begin{array}{l}51 \\
(16 \%)\end{array}$ & $\begin{array}{l}109 \\
(34 \%)\end{array}$ & $\begin{array}{l}133 \\
(41 \%)\end{array}$ & $\begin{array}{l}\text { Others find it easy to trust } \\
\text { this manager }\end{array}$ \\
\hline
\end{tabular}

\subsubsection{Self-development}

The second dimension, self-development, was comprised of five attributes: (1) REM seeks feedback from knowledgeable others, (2) REM is receptive to constructive criticism, (3) REM takes direction well, (4) REM is open to new ideas, and (5) REM deals with facts when deciding on issues. As was true for the intrinsic qualities, evaluators gave their REM high marks on self development. Seventy-six percent or more of the REMs were given scores above average (see Table 2). 
Negative evaluations on this dimension ranged from a low of four to a high of 10; the average negative percentage was 6.2. Of the five questions, $10 \%$ rated their REM negatively relative to not seeking feedback from others who are more knowledgeable. On the other hand, only 4\% rated their REM negatively on not being open to new ideas.

Table 2. Senior executive evaluations of their REM on self-development dimension - row percentages

\begin{tabular}{|c|c|c|c|c|c|c|}
\hline & \multicolumn{2}{|c|}{ Negative } & \multirow{2}{*}{$\begin{array}{l}\text { Medium } \\
3\end{array}$} & \multicolumn{2}{|c|}{ Positive } & \\
\hline & 1 & 2 & & 4 & 5 & \\
\hline $\begin{array}{l}\text { This manager does not seek } \\
\text { feedback from others who are } \\
\text { more knowledgeable }\end{array}$ & $\begin{array}{l}5 \\
(2 \%)\end{array}$ & $\begin{array}{l}27 \\
(8 \%)\end{array}$ & $\begin{array}{l}29 \\
(9 \%)\end{array}$ & $\begin{array}{l}106 \\
(33 \%)\end{array}$ & $\begin{array}{l}157 \\
(48 \%)\end{array}$ & $\begin{array}{l}\text { This manager seeks feedback } \\
\text { for projects from others who } \\
\text { are more knowledgeable }\end{array}$ \\
\hline $\begin{array}{l}\text { This manager is not receptive to } \\
\text { constructive criticism }\end{array}$ & $\begin{array}{l}4 \\
(1 \%)\end{array}$ & $\begin{array}{l}27 \\
(8 \%)\end{array}$ & $\begin{array}{l}44 \\
(14 \%)\end{array}$ & $\begin{array}{l}114 \\
(35 \%)\end{array}$ & $\begin{array}{l}134 \\
(42 \%)\end{array}$ & $\begin{array}{l}\text { This manager is receptive to } \\
\text { constructive criticism }\end{array}$ \\
\hline $\begin{array}{l}\text { This manager does not take } \\
\text { direction well }\end{array}$ & $\begin{array}{l}0 \\
(0 \%)\end{array}$ & $\begin{array}{l}19 \\
(7 \%)\end{array}$ & $\begin{array}{l}43 \\
(13 \%)\end{array}$ & $\begin{array}{l}92 \\
(28 \%)\end{array}$ & $\begin{array}{l}169 \\
(52 \%)\end{array}$ & $\begin{array}{l}\text { This manager takes direction } \\
\text { well }\end{array}$ \\
\hline $\begin{array}{l}\text { This manager is not open to new } \\
\text { ideas }\end{array}$ & $\begin{array}{l}1 \\
(0 \%)\end{array}$ & $\begin{array}{l}12 \\
(4 \%)\end{array}$ & $\begin{array}{l}32 \\
(10 \%)\end{array}$ & $\begin{array}{l}93 \\
(29 \%)\end{array}$ & $\begin{array}{l}184 \\
(57 \%)\end{array}$ & $\begin{array}{l}\text { This manager is open to new } \\
\text { ideas }\end{array}$ \\
\hline $\begin{array}{l}\text { This manager does not deal with } \\
\text { facts when deciding on issues }\end{array}$ & $\begin{array}{l}3 \\
(1 \%)\end{array}$ & $\begin{array}{l}13 \\
(4 \%)\end{array}$ & $\begin{array}{l}47 \\
(15 \%)\end{array}$ & $\begin{array}{l}131 \\
(41 \%)\end{array}$ & $\begin{array}{l}126 \\
(39 \%)\end{array}$ & $\begin{array}{l}\text { This manager deals with facts } \\
\text { when deciding on issues }\end{array}$ \\
\hline
\end{tabular}

\subsubsection{Outlook}

The third dimension evaluated REMs on six qualities that reflect on the perceived mental state that the REM exhibits. Attributes included in this dimension were: (1) being self assured, (2) showing respect to superiors, (3) having a positive mental attitude, (4) being in control of their emotions, (5) enjoying the work, and (6) having a good sense of humor. Evaluators gave high marks to their REMs' outlook. Seventy-six or more percent rated their REMs as excellent or superior on the six attributes (see Table 3).

Table 3. Senior executive evaluations of their REM on outlook dimension - row percentages

\begin{tabular}{|c|c|c|c|c|c|c|}
\hline & \multicolumn{2}{|c|}{ Negative } & \multirow{2}{*}{$\begin{array}{l}\text { Medium } \\
3\end{array}$} & \multicolumn{2}{|c|}{ Positive } & \\
\hline & 1 & 2 & & 4 & 5 & \\
\hline $\begin{array}{l}\text { This manager is not } \\
\text { sufficiently self-assured }\end{array}$ & $\begin{array}{l}2 \\
(1 \%)\end{array}$ & $\begin{array}{l}20 \\
(6 \%)\end{array}$ & $\begin{array}{l}56 \\
(17 \%)\end{array}$ & $\begin{array}{l}130 \\
(40 \%)\end{array}$ & $\begin{array}{l}116 \\
(36 \%)\end{array}$ & $\begin{array}{l}\text { This manager is sufficiently } \\
\text { self-assured }\end{array}$ \\
\hline $\begin{array}{l}\text { This manager does not show } \\
\text { appropriate respect to his } \\
\text { superiors }\end{array}$ & $\begin{array}{l}4 \\
(1 \%)\end{array}$ & $\begin{array}{l}9 \\
(3 \%)\end{array}$ & $\begin{array}{l}25 \\
(8 \%)\end{array}$ & $\begin{array}{l}90 \\
(28 \%)\end{array}$ & $\begin{array}{l}194 \\
(60 \%)\end{array}$ & $\begin{array}{l}\text { This manager shows } \\
\text { appropriate respect to his } \\
\text { superiors }\end{array}$ \\
\hline $\begin{array}{l}\text { This manager does not have } \\
\text { a positive mental attitude }\end{array}$ & $\begin{array}{l}1 \\
(0 \%)\end{array}$ & $\begin{array}{l}7 \\
(2 \%)\end{array}$ & $\begin{array}{l}25 \\
(8 \%)\end{array}$ & $\begin{array}{l}90 \\
(28 \%)\end{array}$ & $\begin{array}{l}201 \\
(62 \%)\end{array}$ & $\begin{array}{l}\text { This manager has a positive } \\
\text { mental attitude }\end{array}$ \\
\hline $\begin{array}{l}\text { This manager is not in } \\
\text { control of his emotions }\end{array}$ & $\begin{array}{l}2 \\
(1 \%)\end{array}$ & $\begin{array}{l}27 \\
(8 \%)\end{array}$ & $\begin{array}{l}43 \\
(13 \%)\end{array}$ & $\begin{array}{l}110 \\
(34 \%)\end{array}$ & $\begin{array}{l}140 \\
(44 \%)\end{array}$ & $\begin{array}{l}\text { This manager is in control } \\
\text { of his emotions }\end{array}$ \\
\hline $\begin{array}{l}\text { This manager does not enjoy } \\
\text { his work }\end{array}$ & $\begin{array}{l}0 \\
(0 \%)\end{array}$ & $\begin{array}{l}6 \\
(2 \%)\end{array}$ & $\begin{array}{l}23 \\
(7 \%)\end{array}$ & $\begin{array}{l}105 \\
(33 \%)\end{array}$ & $\begin{array}{l}186 \\
(58 \%)\end{array}$ & $\begin{array}{l}\text { This manager enjoys his } \\
\text { work }\end{array}$ \\
\hline $\begin{array}{l}\text { This manager does not have } \\
\text { a good sense of humor }\end{array}$ & $\begin{array}{l}2 \\
(1 \%)\end{array}$ & $\begin{array}{l}10 \\
(3 \%)\end{array}$ & $\begin{array}{l}26 \\
(8 \%)\end{array}$ & $\begin{array}{l}109 \\
(34 \%)\end{array}$ & $\begin{array}{l}173 \\
(54 \%)\end{array}$ & $\begin{array}{l}\text { This manager has a good } \\
\text { sense of humor }\end{array}$ \\
\hline
\end{tabular}

\subsection{Management skills}

The fourth dimension evaluated REMs on 11 qualities that reflect on the management skills of the REM (see Table 4). Included in this category were: (1) handling difficult people or situations with diplomacy, (2) understanding organizational politics, (3) confronting others about their mistakes, (4) setting challenging goals for staff, (5) exercising authority easily, (6) reading other people's emotions well, (7) working easily with others, (8) being sensitive when communicating with diverse cultures, (9) using various techniques to influence others, (10) building rapport with peers and others on the management team, and (11) communicating directly about controversial issues. 
None of the previous attributes received less than $75 \%$ above average scores, 7 out of the 11 attributes on management skills did not reach the $75 \%$ threshold. More negative evaluations were given to the following: (1) REM can read other people's emotions well (54\% above average; 14\% below average scores); (2) REM understands politics in the organization (60\% above average and 13\% below average scores); (3) REM uses a variety of techniques to influence others (61\% above average and 13\% below average scores); (4) the manager handles difficult people or situations with diplomacy (65\% above average and 10\% below average); (5) REM confronts others about their mistakes (64\% above average, 9\% below average); (6) REM communicates directly about controversial issues (70\% above average, $8 \%$ below average); and (7) the manager exercises authority easily (65\% above average and $9 \%$ below average).

Of the four dimensions identified above, the management skills category garnered the highest proportion of negative evaluations of the REMs. This shows the importance of developing managerial skills and where additional training might be most useful for entry level managers.

Table 4. Senior executive evaluations of their REM on management skills dimension - row percentages

\begin{tabular}{|c|c|c|c|c|c|c|}
\hline & \multicolumn{2}{|c|}{ Negative } & \multirow{2}{*}{$\begin{array}{l}\text { Medium } \\
3\end{array}$} & \multicolumn{2}{|c|}{ Positive } & \\
\hline & 1 & 2 & & 4 & 5 & \\
\hline $\begin{array}{l}\text { This manager does not set } \\
\text { challenging goals for his staff }\end{array}$ & $\begin{array}{l}4 \\
(1 \%)\end{array}$ & $\begin{array}{l}27 \\
(5 \%)\end{array}$ & $\begin{array}{l}44 \\
(19 \%)\end{array}$ & $\begin{array}{l}107 \\
(33 \%)\end{array}$ & $\begin{array}{l}134 \\
(42 \%)\end{array}$ & $\begin{array}{l}\text { This manager sets } \\
\text { challenging goals for his staff }\end{array}$ \\
\hline $\begin{array}{l}\text { This manager does not } \\
\text { exercise authority easily }\end{array}$ & $\begin{array}{l}3 \\
(1 \%)\end{array}$ & $\begin{array}{l}26 \\
(8 \%)\end{array}$ & $\begin{array}{l}84 \\
(26 \%)\end{array}$ & $\begin{array}{l}128 \\
(40 \%)\end{array}$ & $\begin{array}{l}82 \\
(25 \%)\end{array}$ & $\begin{array}{l}\text { This manager exercises } \\
\text { authority easily }\end{array}$ \\
\hline $\begin{array}{l}\text { This manager cannot read } \\
\text { other people's emotions well }\end{array}$ & $\begin{array}{l}11 \\
(3 \%)\end{array}$ & $\begin{array}{l}35 \\
(11 \%)\end{array}$ & $\begin{array}{l}106 \\
(33 \%)\end{array}$ & $\begin{array}{l}116 \\
(35 \%)\end{array}$ & $\begin{array}{l}57 \\
(18 \%)\end{array}$ & $\begin{array}{l}\text { This manager can read other } \\
\text { people's emotions well }\end{array}$ \\
\hline $\begin{array}{l}\text { It is not easy for this manager } \\
\text { to work with others }\end{array}$ & $\begin{array}{l}1 \\
(0 \%)\end{array}$ & $\begin{array}{l}22 \\
(7 \%)\end{array}$ & $\begin{array}{l}46 \\
(14 \%)\end{array}$ & $\begin{array}{l}100 \\
(31 \%)\end{array}$ & $\begin{array}{l}155 \\
(48 \%)\end{array}$ & $\begin{array}{l}\text { It is easy for this manager to } \\
\text { work with others }\end{array}$ \\
\hline $\begin{array}{l}\text { This manager is not sensitive } \\
\text { to culturally correct behavior } \\
\text { when communicating with } \\
\text { diverse cultures }\end{array}$ & $\begin{array}{l}2 \\
(1 \%)\end{array}$ & $\begin{array}{l}12 \\
(4 \%)\end{array}$ & $\begin{array}{l}51 \\
(16 \%)\end{array}$ & $\begin{array}{l}119 \\
(36 \%)\end{array}$ & $\begin{array}{l}138 \\
(43 \%)\end{array}$ & $\begin{array}{l}\text { This manager is sensitive to } \\
\text { culturally correct behavior } \\
\text { when communicating with } \\
\text { diverse cultures }\end{array}$ \\
\hline $\begin{array}{l}\text { This manager does not } \\
\text { confront others about their } \\
\text { mistakes }\end{array}$ & $\begin{array}{l}3 \\
(1 \%)\end{array}$ & $\begin{array}{l}26 \\
(8 \%)\end{array}$ & $\begin{array}{l}86 \\
(27 \%)\end{array}$ & $\begin{array}{l}134 \\
(42 \%)\end{array}$ & $\begin{array}{l}72 \\
(22 \%)\end{array}$ & $\begin{array}{l}\text { This manager confronts } \\
\text { others about their mistakes }\end{array}$ \\
\hline $\begin{array}{l}\text { This manager does not handle } \\
\text { difficult people or situations } \\
\text { with diplomacy }\end{array}$ & $\begin{array}{l}3 \\
(1 \%)\end{array}$ & $\begin{array}{l}29 \\
(9 \%)\end{array}$ & $\begin{array}{l}77 \\
(24 \%)\end{array}$ & $\begin{array}{l}120 \\
(38 \%)\end{array}$ & $\begin{array}{l}91 \\
(28 \%)\end{array}$ & $\begin{array}{l}\text { This manager handles } \\
\text { difficult people or situations } \\
\text { with diplomacy }\end{array}$ \\
\hline $\begin{array}{l}\text { This manager does not } \\
\text { understand politics in the } \\
\text { organization }\end{array}$ & $\begin{array}{l}10 \\
(3 \%)\end{array}$ & $\begin{array}{l}34 \\
(10 \%)\end{array}$ & $\begin{array}{l}86 \\
(27 \%)\end{array}$ & $\begin{array}{l}121 \\
(38 \%)\end{array}$ & $\begin{array}{l}69 \\
(22 \%)\end{array}$ & $\begin{array}{l}\text { This manager understands } \\
\text { politics in the organization }\end{array}$ \\
\hline $\begin{array}{l}\text { This manager fails to } \\
\text { communicate directly about } \\
\text { controversial issues }\end{array}$ & $\begin{array}{l}3 \\
(1 \%)\end{array}$ & $\begin{array}{l}25 \\
(8 \%)\end{array}$ & $\begin{array}{l}69 \\
(21 \%)\end{array}$ & $\begin{array}{l}138 \\
(43 \%)\end{array}$ & $\begin{array}{l}87 \\
(27 \%)\end{array}$ & $\begin{array}{l}\text { This manager communicates } \\
\text { directly about controversial } \\
\text { issues }\end{array}$ \\
\hline $\begin{array}{l}\text { This manager does not use a } \\
\text { variety of techniques to } \\
\text { influence others }\end{array}$ & $\begin{array}{l}8 \\
(3 \%)\end{array}$ & $\begin{array}{l}32 \\
(10 \%)\end{array}$ & $\begin{array}{l}86 \\
(27 \%)\end{array}$ & $\begin{array}{l}130 \\
(41 \%)\end{array}$ & $\begin{array}{l}62 \\
(19 \%)\end{array}$ & $\begin{array}{l}\text { This manager uses a variety } \\
\text { of techniques to influence } \\
\text { others }\end{array}$ \\
\hline $\begin{array}{l}\text { This manager does not build } \\
\text { rapport with peers and others } \\
\text { on the management team }\end{array}$ & $\begin{array}{l}3 \\
(1 \%)\end{array}$ & $\begin{array}{l}20 \\
(6 \%)\end{array}$ & $\begin{array}{l}47 \\
(15 \%)\end{array}$ & $\begin{array}{l}125 \\
(39 \%)\end{array}$ & $\begin{array}{l}127 \\
(39 \%)\end{array}$ & $\begin{array}{l}\text { This manager builds rapport } \\
\text { with peers and others on the } \\
\text { management team }\end{array}$ \\
\hline
\end{tabular}

\subsection{Post-graduate school employment}

The challenge early-careerists confront is particularly acute for students who obtain prestigious administrative fellowships. For a year to two years, these students are able to work with the president and other senior executives, completing projects that advance their knowledge in some vital direction that the organization is pursuing. At the 
conclusion of the fellowship experience, early careerists are generally recruited to entry level positions. Like many of their peer millennials, they can become frustrated and can begin seeking positions that will allow them to regain the management stature and access to senior leaders in other organizations ${ }^{[11,12]}$.

The Pew Research Center reported that millennials are job hoppers and see their current position as either a steppingstone to a career or just a job to help them get by ${ }^{[1]}$. Six in ten (61\%) expect to be working for someone else while $37 \%$ indicate they will never leave their current employer. What should organizations do to retain the talent of these millennials, particularly when there has been a tremendous organizational investment in them? Who in the organization is responsible for identifying the problem and investing the resources to retain this young talent?

If the Mayo Clinic is correct, then listening to the millennials, challenging their interests, providing mentors, and giving feedback requires a cultural change in an organization ${ }^{[2]}$. Senior leaders have to be convinced that the status quo will not keep talented millennials in an organization because the millennials need to be brought into leadership. Anecdotally, it is often reported that the organizational hierarchy and norms that retained baby boomers on the job will not work with millennials. In health care, job satisfaction and being valued, are key satisfiers for the millennials ${ }^{[13]}$.

\subsection{REMs' competencies compared with evaluators' own competencies at the same career stage}

One way to determine if today's young managers are up to par is to ask senior executives to compare their REM's competence with their own abilities when they entered the profession. As shown in Table 5, six areas of competence were presented. It appears that a sizeable majority of respondents evaluated their REM favorably compared to themselves at the same career stage.

The table shows that fully $62 \%$ of REMs were deemed about the same or more competent than their evaluators in developing others. Sixty-three percent of REMs were deemed about the same or more competent in marketing/strategic planning. Senior executives evaluated their REMs as about the same or more competent compared to themselves in communications (66\%), problem solving (70\%) and interpersonal skills (70\%). Although the senior executives viewed the REM favorably, the areas where the REM was evaluated as less competent were in managerial ethics and values (15\%); communications (33\%); problem-solving (30\%); interpersonal skills (30\%); developing others (39\%); and marketing/ strategic planning (37\%).

Table 5. Senior executives' appraisal of their REM's competencies in relation to their own at the same stage of their career - row percentages

\begin{tabular}{llll}
\hline Competencies & Much Worse/Worse & About the same & Better/Much better \\
\hline a. Managerial ethics \& values & $47(15 \%)$ & $222(71 \%)$ & $42(14 \%)$ \\
b. Communication & $105(33 \%)$ & $136(43 \%)$ & $74(24 \%)$ \\
c. Problem solving & $93(30 \%)$ & $167(54 \%)$ & $50(16 \%)$ \\
d. Interpersonal skills & $92(30 \%)$ & $153(50 \%)$ & $62(20 \%)$ \\
e. Developing others & $121(39 \%)$ & $156(50 \%)$ & $37(11 \%)$ \\
f. Marketing/Strategic Planning. & $114(37 \%)$ & $117(38 \%)$ & $78(25 \%)$ \\
\hline
\end{tabular}

\subsection{Rating of REMS' interpersonal skills with other role incumbents}

Table 6 shows the overall evaluation given by senior executives of the REMs relative to supervisors, peers, subordinates and physicians. To provide the evaluation, senior executives gave their REM a score on a scale ranging from one (poor) to five (excellent). For the purposes of this research, scores were collapsed into three general categories: below average (scores 1-2), average (3) and above average (4-5). 
It can be seen that REMs were evaluated differently depending on who was being discussed. For example over $60 \%$ rated the REMs above average in relating to their supervisor or to peers and fewer than $10 \%$ rated their REMs below average in dealing with these groups. On the other hand, about half of evaluators rated their REM above average when dealing with subordinates or physicians and the proportion rating their REM below average was $13 \%$ for subordinates and $11 \%$ for physicians.

Overall, summary measure of the REMS' interpersonal skills showed that $18 \%$ of the evaluators rated their REMs as average, $74 \%$ rated their REM above average and $7 \%$ rated them below average.

Table 6. Senior executives' ratings of the interpersonal skills of their REM - row percentages

\begin{tabular}{|c|c|c|c|c|c|}
\hline & \multicolumn{2}{|c|}{ Poor (\%) } & \multirow{2}{*}{$\begin{array}{l}\text { Average (\%) } \\
3\end{array}$} & \multicolumn{2}{|c|}{ Excellent (\%) } \\
\hline & 1 & 2 & & 4 & 5 \\
\hline Supervisor & $1(1 \%)$ & $16(5 \%)$ & $53(17 \%)$ & $121(40 \%)$ & 113 (37\%) \\
\hline Peers & $2(1 \%)$ & 20 (7\%) & 56 (18\%) & 125 (40\%) & 109 (35\%) \\
\hline Subordinates & $4(1 \%)$ & 38 (12\%) & 63 (21\%) & 107 (34\%) & 99 (32\%) \\
\hline Physicians & $2(1 \%)$ & 31 (10\%) & 66 (21\%) & 110 (35\%) & 101 (33\%) \\
\hline Overall & $1(1 \%)$ & $22(7 \%)$ & 55 (18\%) & 127 (41\%) & 102 (33\%) \\
\hline
\end{tabular}

\subsection{Working with the recent entry manager}

In Table 7, the data reveal that the working relationship that is statistically significant in working with a recent entrant manager involves a senior executive who is an immediate supervisor or in a work group where knowledge can be transferred. There is no statistical significance for a senior executive serving as a formal mentor, informal mentor or with a nearby office. The REM needs to have an ongoing relationship to learn from the senior executive. Having the opportunity to interact and observe the senior executive in a supervisory role and in work groups where there is interaction to resolve issues, may be the best methods to enhance the REM's interpersonal skills.

Table 7. Capacity in which senior executives interact with REM, by cohort

\begin{tabular}{lllllll}
\hline Senior Executives & $\begin{array}{l}\text { Immediate } \\
\text { Supervisor }\end{array}$ & $\begin{array}{l}\text { Formal } \\
\text { Mentor }\end{array}$ & $\begin{array}{l}\text { Informal } \\
\text { Mentor }\end{array}$ & $\begin{array}{l}\text { Work } \\
\text { Group }\end{array}$ & $\begin{array}{l}\text { Office } \\
\text { Nearby }\end{array}$ & Total \\
\hline Gen X (Age 28-46) & $35(52 \%)$ & $11(16 \%)$ & $12(18 \%)$ & $4(6 \%)$ & $5(8 \%)$ & 67 \\
Younger Boomer (Age 47-56) & $58(41 \%)$ & $22(16 \%)$ & $31(22 \%)$ & $24(17 \%)$ & $5(4 \%)$ & 140 \\
Older Boomer (Age 57-66) & $49(32 \%)$ & $19(12 \%)$ & $38(25 \%)$ & $35(22 \%)$ & $14(9 \%)$ & 156 \\
Chi-Square $p$-value & $.043^{*}$ & .777 & .325 & $.003^{* *}$ & .536 & 363 \\
\hline
\end{tabular}

${ }^{* *}<.01 ;{ }^{*}<.05$

\subsection{I dentifying fast trackers in the organization}

The researchers wanted to determine whether or not healthcare organizations identify fast-trackers and how organizations respond, if at all, to enhance the REMs' interpersonal skills and integrate them into the organization. For example, in previous research works, fast-trackers were identified as ambitious, creative, independent, and intelligent employees who exhibit leadership potential ${ }^{[14,15]}$. They were considered to be "officer material" and were given high exposure positions and assigned projects with senior management. In the ACHE study, eighty-two percent of senior executive respondents indicated that interpersonal relationship skills were used to identify "fast trackers" and potential successors to current leaders in their organization.

\section{Strategies and programs that enhance interpersonal skills of recent entrant managers}

In the survey, there was an open-ended question where 181 senior executive respondents identified what they perceived to 
be useful strategies and programs that enhanced the interpersonal skills of recent entrant managers. Figure 2 indicates that their comments were classified into seven major categories that included on-the-job training; formal in-house training; coaching/mentoring; external training; leadership assessment; recruitment interviews; and no formal training. Coaching/ mentoring (28\%), formal in-house training (26\%) and on-the-job training (25\%) were the most common methods used to bring the REM into the organization and orient him/her to the work setting. Where external training (10\%) was provided, the senior executive respondent recommended ACHE seminars, Vital Smarts training, and enrollment in graduate education programs. Six percent identified personality and leadership assessment tools that were administered in their organization to identify management leaders. Five percent of the respondents viewed the recruitment process as being critical to the success of a recent entrant manager and thought recruitment for organizational fit was important in bringing the right candidates who would ultimately be successful into the organization.

Research indicates that REMs have trust in institutions and believe that their accomplishments will be rewarded with acknowledgment, encouragement, and access ${ }^{[12]}$. Managers complain that they are constantly interrupted by REMs to answer questions because REMs seek guidance and direction ${ }^{[16]}$. For healthcare organizations, providing the coaching and mentoring assistance and the opportunity for REMs to develop skills in work groups with senior executives are critical to the REMs development. In addition, REMs thrive in organizations that create a clear path to success by identifying employees' ideal skills, creating realistic timelines for promotions, and detailing career progression ${ }^{[16]}$. Clearly teamwork, mentoring, and collaboration between REMs and senior executives will allow REMs to develop their interpersonal skills.

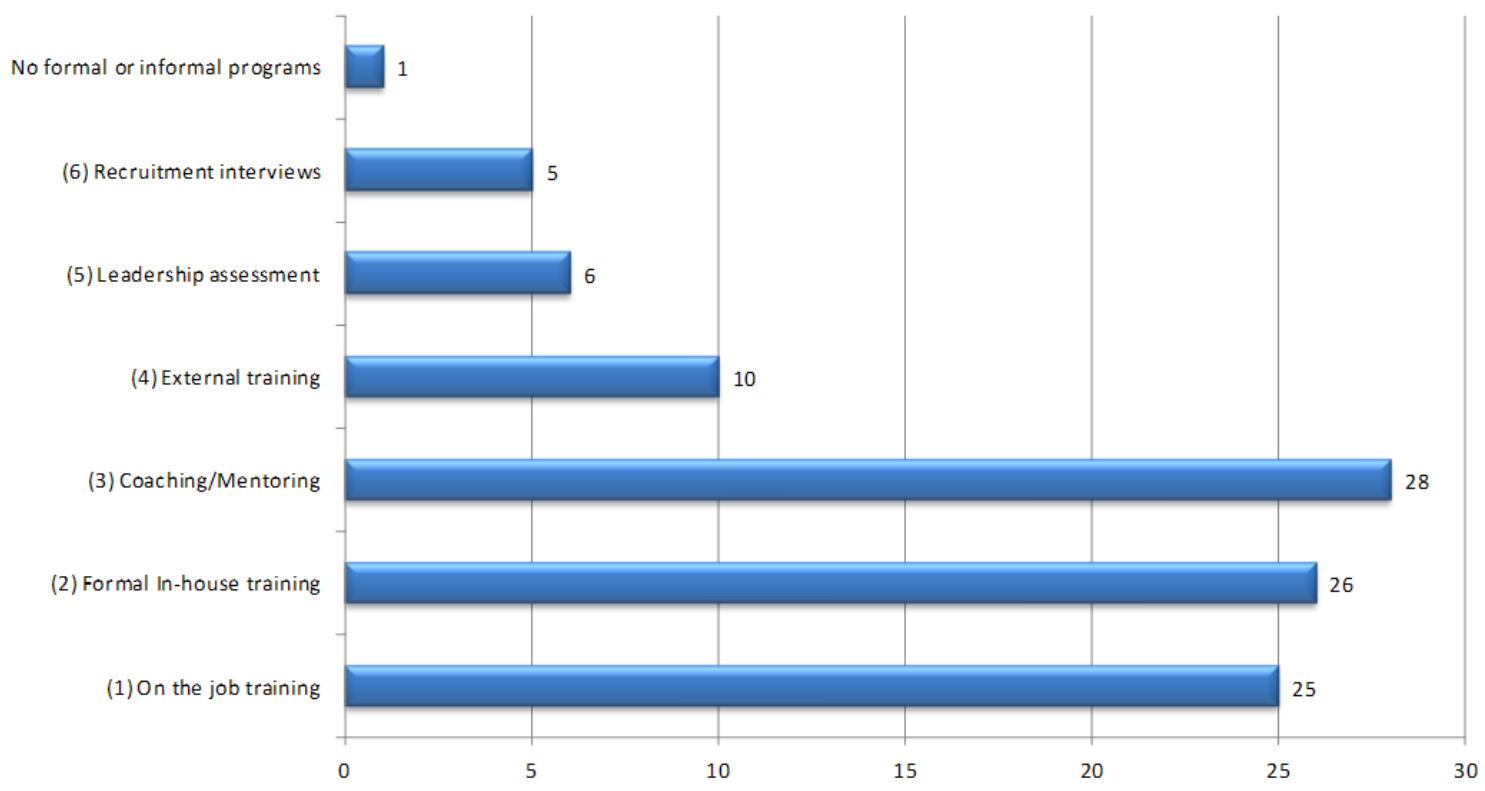

Figure 2. Strategies and programs that enhance interpersonal skills (percent)

(1) Meeting participation, Group projects, Listening rounds, Employee forums, Project work, Role modeling

(2) Manager orientation training, Talent management course, Leadership training

(3) Mentor and role playing, 1-on-1 interaction, Peer coaching, Mentoring with senior management

(4) ACHE seminars, Crucial conversations, Leadership Institute, Press-Ganey, Studer Group, University MBA

(5) AONE assessment, Myers-Briggs, 360-feedback

(6) Hire for attitude, Hire for organizational fit, Behavioral interviews

\section{Future research}

The research conducted offers the opportunity to delve more deeply into the correlates of successful interpersonal relationships. Areas for further research would be to conduct multivariate analyses to help identify the strongest correlates 
of interpersonal skills among the REMs. Also, special analyses could be conducted to determine if those organizations that have codified methods to nurture interpersonal proficiency benefit from such programs. Future research would determine if REMS remain longer with the organization, are promoted more rapidly, and whether human resource outcomes are impacted by less absenteeism, higher morale, and higher quality of care.

\section{Conclusion}

The generation divide in the workplace may be overstated when it comes to healthcare management. The senior executives that responded to a survey on the interpersonal skills of recent entrant managers in their organization favorably evaluated the manager's values, honesty, and trust characteristics, the ability to seek feedback, being receptive to constructive criticism, taking direction well, being open to new ideas, and dealing with facts when deciding on issues. In addition, senior executives rated the recent entrant manager favorably on being self-assured, showing respect to superiors, having a positive mental attitude, being in control of their emotions, enjoying their work, and having a sense of humor.

Areas where the recent entrant manager requires more training are in the management domain. Negative evaluations were given in the REM's ability to read other people's emotions well, understanding politics in the organization, using a variety of techniques to influence others, managing difficult people or situations with diplomacy, confronting others about their mistakes, communicating about controversial issues, and exercising authority. This analysis helps to show the importance of developing managerial skills and where additional training might be most useful for entry level managers.

Senior executives who work with recent entrant managers are favorably impressed with the skills they bring to the work environment particularly in the area of managerial ethics and values. Areas for improvement were communication, problem solving, inter-personal skills, developing others, and marketing/strategic planning. Senior executives who serve as an immediate supervisor or serve in workgroups with REMs have a greater impact on their development. Senior executives acknowledged that their organizations use interpersonal skills to identify fast-trackers for advancement with coaching/mentoring, formal in-house training, and on-the-job training being the strategies that are deployed most often to transition the REM into leadership roles.

\section{Funding}

This research was funded by the American College of Healthcare Executives, 2010 Health Management Research Award. The Rush University Fund Code: 56454.

\section{Conflict of interests}

The authors declare that they have no conflict of interests.

\section{References}

[1] Pew Research Center. (2010). Millennials: A portrait of generation next. December 12, 2012. Available from: http://www.pewresearch.org/ millennials

[2] Mayo Clinic. Workplace generation gap: Understand differences among colleagues. September 9, 2007. Available from: http://www.mayoclinic.com/health/working-life (March 29, 2007)

[3] Howe, N., W. Strauss. Millennials rising: The next great generation. New York: Vintage Books. 2000.

[4] Alsop, R. The trophy kids grow up: How the Millennial generation is shaking up the workplace. San Francisco: Jossey-Bass Publishers. 2008.

[5] Cahill, T. F., M. Sedrak. The Millennials are here: Addressing generational tensions. Chicago: 2010 Congress on Healthcare Leadership. 2010.

[6] Cahill, T. F., M. Sedrak. Generational jeopardy. HFMA Focus 14-16. 2009.

[7] DeAngelo, L., S. Hurtado, J.H. Pryor, K.R. Kelly, J.L. Santos, W.S. Korn. The American College Teacher: National Norms for the 2007-08 HERI Faculty Survey. Los Angeles: Higher Education Research Institute, UCLA. 2009. 
[8] Commission on Accreditation of Healthcare Management Education. (2013). CAHME Criteria for Accreditation. December 11, 2012. Available from: http://www.cahme.org/resources/fall2013

[9] Hopkins, C. D., M. A. Raymond, L. Carlson. Educating students to give them a sustainable competitive advantage. Journal of Marketing Education. September 12, 2011. Available from: http://www. http://jmd.sagepub.com/content/33/3/337.full.pdf+html

[10] Kelley, C.A., C. Bridges. Introducing professional and career development skills in the marketing curriculum. Journal of Marketing Education. 2005; 27: 212-218. http://dx.doi.org/10.1177/0273475305279526

[11] Fabian, N. The aspect of work that gen x doesn’t know! Journal of Environmental Health. 2010; $73: 58$.

[12] Hershatter, A., M. Epstein. Millennials and the world of work: An organization and management perspective. Journal of Business Psychology. 2010; 25: 211-223. http://dx.doi.org/10.1007/s10869-010-9160-y

[13] Howard, D., D. Silverstein. (2011). The interpersonal skills of recent entrants to the field of healthcare management: Final report. December 13, 2013. Available from: http://www.ache.org/pubs/research/Interpersonal-Skills-of-Recent-Entrants-v312-25-11.pdf

[14] Epstein, M., P. Howes. Recruiting, retaining and managing the millennial generation. Selected readings 2008 - Management of a practice [CD ROM]. New York: American Institute of Certified Public Accountants. 2008.

[15] Gritzmacher, K.J. Staying competitive through strategic management of fast-track employees. National Productivity Review. 1989; 8: 421-432. http://dx.doi.org/10.1002/npr.4040080409

[16] Smith, W. S. (2008). Decoding generational differences: Fact, fiction, or should we just get back to work? January 7, 2013. Available from: http://www.deloitte.com/dtt/cda/doc/content/us_Talent_DecodingGenerational Differences.pdf 